\title{
2020-2021 Vegetable Production Handbook: Chapter 3. Principles and Practices of Irrigation Management for Vegetables ${ }^{1}$
}

\author{
Lincoln Zotarelli, Michael D. Dukes, Eric H. Simonne, and Charles E. Barrett ${ }^{2}$
}

This section contains basic information on vegetable water use and irrigation management, along with some references on irrigation systems. Proper water management planning must consider all uses of water, from the source of irrigation water to plant water use. Therefore, it is very important to differentiate between crop water requirements and irrigation or production-system water requirements. Crop water requirements refer to the actual water needs for evapotranspiration (ET) and plant growth, and they primarily depend on crop development and climatic factors, which are closely related to climatic demands. Irrigation requirements are primarily determined by crop water requirements, but they also depend on the characteristics of the irrigation system, management practices, and the soil characteristics in the irrigated area.

\section{Best Management Practices (BMP) for Irrigation}

BMPs have historically been focused on nutrient management and fertilizer rates. However, because rainfall or irrigation water is the vector of off-site nutrient movement of nitrate in solution and phosphate in sediments as well as other soluble chemicals, proper irrigation management directly affects the efficacy of a BMP plan. The irrigation BMPs in the Water Quality/Quantity Best Management
Practices for Florida Vegetable and Agronomic Crops manual (accessible at https://www.floridaagwaterpolicy.com) cover all major aspects of irrigation, such as irrigation system design, system maintenance, erosion control, and irrigation scheduling.

\section{Uses of Irrigation Water}

Irrigation systems have several uses in addition to water delivery for crop ET. Water is required for a preseason operational test of the irrigation system to check for leaks and to ensure proper performance of the pump and power plant. Irrigation water is also required for field preparation, crop establishment, crop growth and development, withinseason system maintenance, delivery of chemicals, frost protection, and other uses, such as dust control.

\section{Field Preparation}

Field preparation water is used to provide moisture to the field soil for tillage and bed formation. The water used for field preparation depends on specific field cultural practices, initial soil moisture conditions, the depth to the natural water table, and the type of irrigation system. Drip-irrigated fields on sandy soils often require an additional irrigation system for field preparation because drip tubes are not installed until after the beds have been formed. Thus, many

1. This document is CV297, one of a series of the Horticultural Sciences Department, UF/IFAS Extension. Original publication date June 2015. Revised June 2020. Visit the EDIS website at http://edis.ifas.ufl.edu.

2. Lincoln Zotarelli, assistant professor, Horticultural Sciences Department; Michael D. Dukes, professor, Department of Agricultural and Biological Engineering; Eric H. Simonne, professor, Office of District Extension Directors; and Charles E. Barrett, regional specialized agent—northeast, water resources; UF/IFAS Extension, Gainesville, FL 32611.

The Institute of Food and Agricultural Sciences (IFAS) is an Equal Opportunity Institution authorized to provide research, educational information and other services

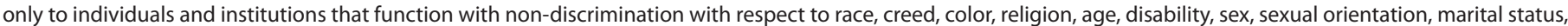

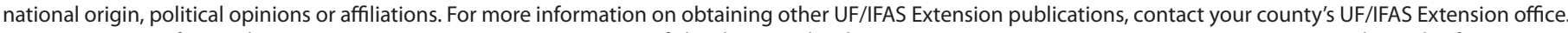
U.S. Department of Agriculture, UF/IFAS Extension Service, University of Florida, IFAS, Florida A \& M University Cooperative Extension Program, and Boards of County Commissioners Cooperating. Nick T. Place, dean for UF/IFAS Extension. 
drip-irrigated vegetable fields may also require an overhead or subirrigation system for field preparation. For example, many strawberry production fields have sprinkler irrigation systems already installed for frost protection. These systems are also used for field preparation and may apply one or more inches of water for this purpose. Subirrigated (seepage) fields use the same system for field preparation as for crop establishment, plant growth needs, and frost protection. Subirrigation water management requirements depend on the soil characteristics within the irrigated field and surrounding areas. Sufficient water must be provided to raise the water table level as high as 18 to 24 in below the soil surface. Water is required to fill the pores of the soil and to satisfy evaporation and subsurface runoff requirements. As a rough guide, 1.0 to 2.5 in of water are required for each foot of water table rise. For example, a field with a pre-irrigation water table 30 in deep may need about 2 in of water to raise the water table to 18 in, while a pre-irrigation water table at 48 in may require 5 in of water for the same result.

\section{Crop Establishment}

Vegetables that are set as transplants, rather than direct seeded, require irrigation for crop establishment in excess of crop ET. Establishment irrigations are used to either keep plant foliage wet by overhead sprinkler irrigation (to avoid desiccation of leaves) or to maintain high soil moisture levels until the root systems increase in size and plants start to actively grow and develop. Establishment irrigation practices vary among crops and irrigation systems. Strawberry plants set as bare-root transplants may require 7 to 14 days of frequent intermittent overhead irrigation for establishment prior to irrigation with the drip system. Practices like intermittent irrigation, use of low-volume sprinklers, and use of crop protectants can reduce the volume of irrigation water required for establishment of strawberries. The amount of water required for crop establishment can range widely depending on crop, irrigation system, and climate demand. Adequate soil moisture is also needed for the uniform establishment of direct-seeded vegetable crops.

\section{Crop Growth and Development}

Irrigation requirements to meet the ET needs of a crop depend on the type of crop, field soil characteristics, irrigation system type and capacity, and crop growth stage. Crops vary in growth characteristics that result in different relative water-use rates. Soils differ in texture and hydraulic characteristics such as available water-holding capacity (AWHC) and capillary movement. Because sands generally have very low AWHC values ( $3 \%$ to $6 \%$ is common), a $1 \%$ change in AWHC affects irrigation practices.

\section{Water Application (Irrigation Requirement)}

Irrigation systems are generally rated with respect to application efficiency (Ea), which is the fraction of the water that has been applied by the irrigation system and that is available to the plant for use (Table 1). Applied water that is not available to the plant may have been lost from the crop root zone through evaporation or wind drifts of spray droplets, leaks in the pipe system, surface runoff, subsurface runoff, or deep percolation within the irrigated area. Irrigation requirements (IR) are determined by dividing the desired amount of water to provide to the plant (ETc) by the Ea as a decimal fraction (Eq.[1]). For example, if it is desired to apply 0.5 in to the crop with a $75 \%$ efficient system, then $0.5 / 0.75=0.67$ in would need to be pumped. Hence, when seasonal water needs are assessed, the amount of water needed should be based on the irrigation requirement and all the needs for water, not only on the crop water requirement. For more information, consult Field Evaluation of Microirrigation Water Application Uniformity at https://edis.ifas.ufl.edu/ae094. Catch cans can be used in the field to measure the actual amount of water applied.

\section{Eq. [1] Irrigation requirement $=$ Crop water requirement / Application efficiency}

$\mathrm{IR}=\mathrm{ETc} / \mathbf{E a}$

\section{Fertigation/Chemigation}

Irrigation systems are often used for delivery of chemicals such as fertilizers, soil fumigants, or insecticides. The crop may require nutrients when irrigation is not required (e.g., after heavy rainfall). Fertilizer injection schedules based on soil test results are provided in Chapter 2 of this production guide. Fertigation should not begin until the system is pressurized. It is recommended to always end a fertigation/ chemigation event with a short flushing cycle with clear water and/or to rinse crop foliage to avoid the accumulation of fertilizer or chemical deposits in the irrigation system. The length of the flushing cycle should be 10 min longer than the travel time of the fertilizer from the irrigation point to the farthest point of the system.

\section{System Maintenance}

Irrigation systems require periodic maintenance throughout the growing season. These activities may require system operation during rainy periods to ensure that the system is ready when needed. In addition, drip irrigation systems may require periodic maintenance to prevent clogging and system failure. Typically, cleaning agents are injected 
weekly, but in some instances more frequent injections are needed.

\section{Frost Protection}

For some crops, irrigation is used for frost protection during winter growing seasons. For strawberry production, sprinkler irrigation is primarily used with application rates of about 0.25 in per hour during freeze events. Water freezes at $32^{\circ} \mathrm{F}$, while most plant tissues freeze at lower temperatures. Overhead freeze protection is efficient for air temperatures as low as $26^{\circ} \mathrm{F}-28^{\circ} \mathrm{F}$, but seldom below. For vegetable fields with subirrigation systems, the relatively higher temperature of groundwater can be used for cold protection. Growers may also irrigate to raise the water table throughout the field. Frost protection water requirements vary depending on the severity and duration of freeze events, the depth to the existing water table level, and field hydraulic characteristics. For more information, consult UF/IFAS bulletin HS931, Microsprinkler Irrigation for Cold Protection of Florida Citrus, at https://edis.ifas. ufl.edu/ch182 and SL296, Citrus Cold Weather Protection and Irrigation Scheduling Tools Using Florida Automated Weather Network (FAWN) Data, at https://edis.ifas.ufl.edu/ ss509.

\section{Other Uses}

Other irrigation uses vary according to the type of crop, system characteristics, and field location. Some examples include: periodic overhead irrigation for dust control; wetting of dry row middles to settle dust and prevent sand from blowing during windy conditions; and wetting of roadways and drive aisles to provide traction for farm vehicles.

\section{Irrigation Scheduling}

Irrigation scheduling consists simply of applying water to crops at the right time and in the right amount, and it is considered an important BMP. The characteristics of the irrigation system, crop needs, soil properties, and atmospheric conditions must all be considered to properly schedule irrigations. Poor timing or insufficient water application can result in crop stress and reduced yields from inappropriate amounts of available water or nutrients. In sandy soils, excessive water applications may reduce yield and quality and increase the risk of nutrient leaching.

A wide range of irrigation scheduling methods is used in Florida, with corresponding levels of water management (Table 2). The recommended method (level 5) for scheduling irrigation (drip or overhead) for vegetable crops is to use together: the crop water requirement method that takes into account plant stage of growth associated with measurements of soil water status, and guidelines for splitting irrigation (see below). A typical irrigation schedule contains (1) a target crop water requirement adjusted to growth stage and actual evaporative demand, (2) adjustment of irrigation application based on soil moisture, (3) a rule for splitting irrigation, (4) a method to account for rainfall, and (5) recordkeeping (Table 3 ). For seepage irrigation, the water table should be maintained near the 18-inch depth (measured from the top of the bed) at planting and near the 24 -inch depth when plants are fully grown. Water tables should be maintained at the proper level to ensure optimum moisture in the bed without leading to oversaturation of the root zone and potential losses of nutrients. Water tables can be monitored with a section of PVC pipe sunk in the soil with a calibrated float inside the PVC pipe. The calibrated float can be used to determine the exact level of the water table. For more information on observation well construction, consult Water Table Measurements and Monitoring for Flatwood Citrus at https://edis.ifas.ufl.edu/ ch151.

\section{Soil Water Status, Soil Water Tension, and Soil Volumetric Water Content}

Generally, two types of sensors may be used for measurements of soil water status: those that measure soil water potential (also called tension or suction) and those that measure volumetric water content. Soil water tension (SWT) represents the magnitude of the suction (water potential, negative pressure) the plant roots have to create to free soil water from the attraction of the soil and move it into the root cells. The drier the soil, the higher the suction needed, hence, the higher SWT. SWT is commonly expressed in centibars $(\mathrm{cb})$ or kilopascals $(\mathrm{kPa} ; 1 \mathrm{cb}=1$ $\mathrm{kPa} ; 7 \mathrm{kPa}=1 \mathrm{psi}$ ). For most vegetable crops grown on the sandy soils of Florida, SWT in the rooting zone should be maintained between 6 (slightly above field capacity) and $15 \mathrm{cb}$. Because of the low AWHC of Florida soils, most full-grown vegetable crops will need to be irrigated daily. During early growth, irrigation may be needed only two to three times weekly. SWT can be measured in the field with moisture sensors or tensiometers. For more information on SWT measuring devices, consult EDIS circular ABE326, Using Tensiometers for Vegetable Irrigation Scheduling in Miami-Dade County at https://edis.ifas.ufl.edu/tr015.

Within the category of volumetric sensors, capacitancebased sensors have become common in recent years due to a decrease in cost of electronic components and increased reliability of these types of sensors. However, sensors 
available on the market have substantially different accuracies, response to salts, and cost. Soil moisture sensors are detailed in the publication, Field Devices for Monitoring Soil Water Content (https://edis.ifas.ufl.edu/ae266). All methods under this definition estimate the volume of water in a sample volume of undisturbed soil ( $\mathrm{ft}^{3} / \mathrm{ft}^{3}$ or percentage). This quantity is useful for determining how saturated the soil is (i.e., what fraction of total soil volume is filled with the soil aqueous solution). When it is expressed in terms of depth (volume of water in soil down to a given depth over a unit surface area [inches of water]), it can be compared with other hydrologic variables like precipitation, evaporation, transpiration, and deep drainage.

\section{Practical Determination of Soil Field Capacity Using Volumetric Soil Moisture Sensors}

It is very important that the irrigation manager understands the concept of "field capacity" to establish an irrigation strategy of providing optimum soil moisture for plant growth, productivity, and reduction of fertilizer nutrient leaching. Figure 1 represents volumetric soil water content (VWC) at depth of 0-6 in measured by a capacitance sensor over a period of 4 days. For the soil field capacity point determination, it is necessary to apply an irrigation depth (or observe a rainfall event) that resulted in saturation of the soil layer, in this particular case $0-6$ in. The depth of irrigation applied was $4,645 \mathrm{gal} / \mathrm{A}$ (equivalent to 0.17 in for overhead or seepage irrigation, or $34 \mathrm{gal} / 100 \mathrm{ft}$ for drip irrigation with 6-foot bed centers in plasticulture) in a single irrigation event. Right after the irrigation events, there was a noticeable increase in soil moisture content. The degree to which the VWC increases, however, is dependent upon volume of irrigation, which is normally set by the duration of irrigation event. For plastic-mulched drip irrigation in sandy soils, long irrigation events result in a relatively large increase in soil moisture in the area below the drip emitter. The spike in soil moisture appears to only be temporary, because the irrigation water rapidly drains down beyond the 6-inch zone (observed by the decrease in VWC). This rapid spike in soil water content indicates that the VWC rapidly reaches a point above the soil water-holding capacity, and the water percolated down to deeper soil layers. For sandy soils, the change in the slope of drainage and extraction lines, in other words, changing from "rapid" to "slower" decrease in soil water content, can be assumed as the "field capacity point." At this time, the water has moved out from the large soil pores (macropores), and its place has been taken by air. The remaining pore spaces (micropores) are still filled with water and will supply the plants with needed moisture. Between the end of day 1 and day 3, the VWC declined at a constant rate as a result of drainage, but most of the water extraction was due to evapotranspiration during the day.

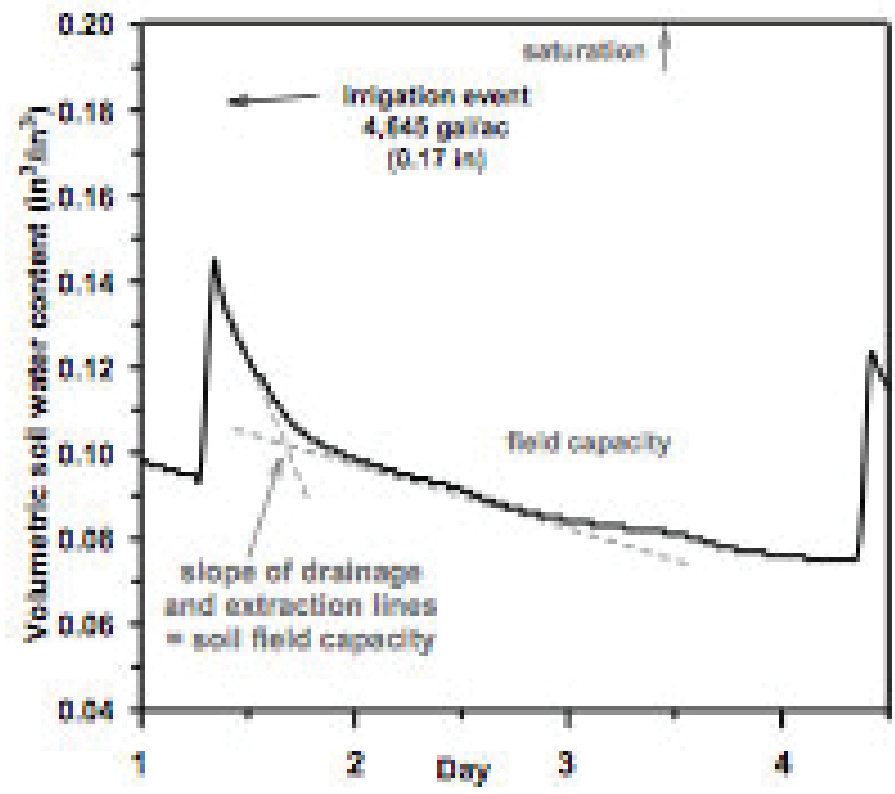

Figure 1. Example of practical determination of soil field capacity at 0-6 inches soil depth after irrigation event using soil moisture sensors.

\section{Examples of Irrigation Scheduling Using Volumetric Soil Moisture Sensor Devices}

In this section, two examples of irrigation management of vegetable crops in sandy soils using soil moisture sensor readings are provided: one example with excessive ("over") irrigation (Figure 2) and one with adequate irrigation (Figure 3 ) using plasticulture. In Figure 2, the irrigation events consisted of the application of a single daily irrigation event of $4,718 \mathrm{gal} / \mathrm{A}$ (equivalent to 0.18 in for overhead or seepage irrigation, or $36 \mathrm{gal} / 100 \mathrm{ft}$ for drip irrigation with 6-foot bed centers in plasticulture. After each irrigation event, there was an increase in the soil water content followed by rapid drainage. Large rainfall events may lead to substantial increases in soil moisture content. On day 2, right after the irrigation, a large rainfall of 0.44 in occurred, which resulted in a second spike of soil water content in the same day. The following irrigation (day 3 ) started when the volumetric soil water content was above the soil field capacity. In this case, the irrigation event of the day 3 could have been safely skipped. Between day 3 and 6 , no irrigation was applied to the crop. The volumetric water content decreased from 0.14 to $0.08 \mathrm{in}^{3} / \mathrm{in}^{3}$. Due to the very low water-holding capacity of the sandy soils, skipping irrigation for several days could lead to unneeded crop water stress, especially during very hot or very windy days (when high evapotranspiration rates may occur), or during flowering/fruit development stage. Between day 6 and 10, 
large daily irrigation events were repeated, exceeding the "safe irrigation zone" and leading to more water drainage and nutrient leaching.

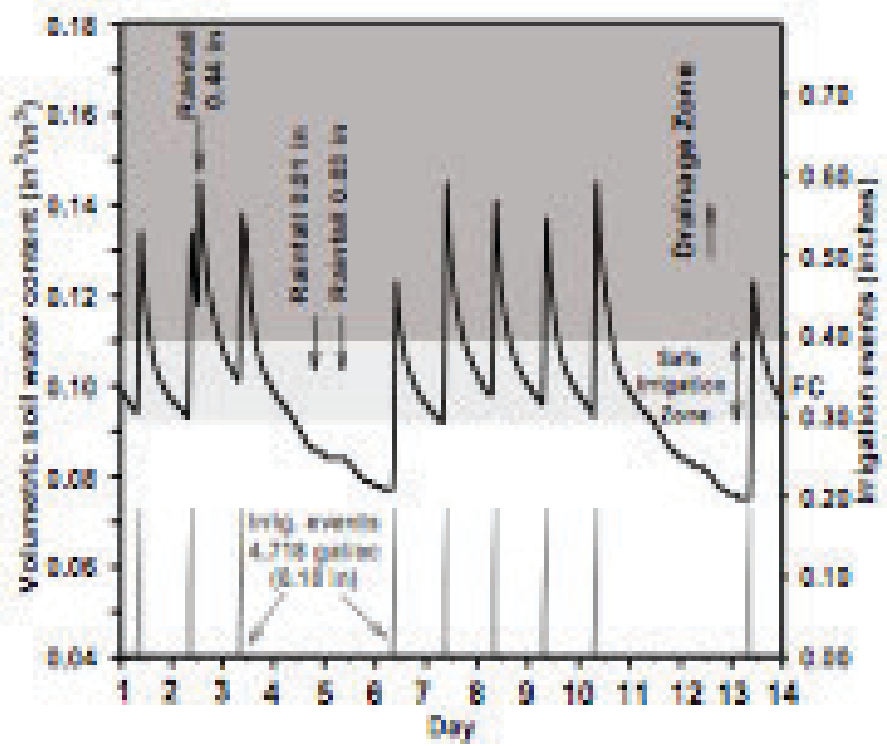

Figure 2. Example of excessive ("over") irrigation of the upper soil layer (0-to-6-inch depth) moisture content for drip irrigation under plasticmulched conditions for sandy soils. The black line indicates volumetric soil water content using soil moisture sensors. The gray line indicates irrigation events, each single daily irrigation event having a volume application of $65 \mathrm{gal} / 100 \mathrm{ft}$ (0.18 in). The dotted line indicates soil field capacity line. Arrows indicate rainfall events.

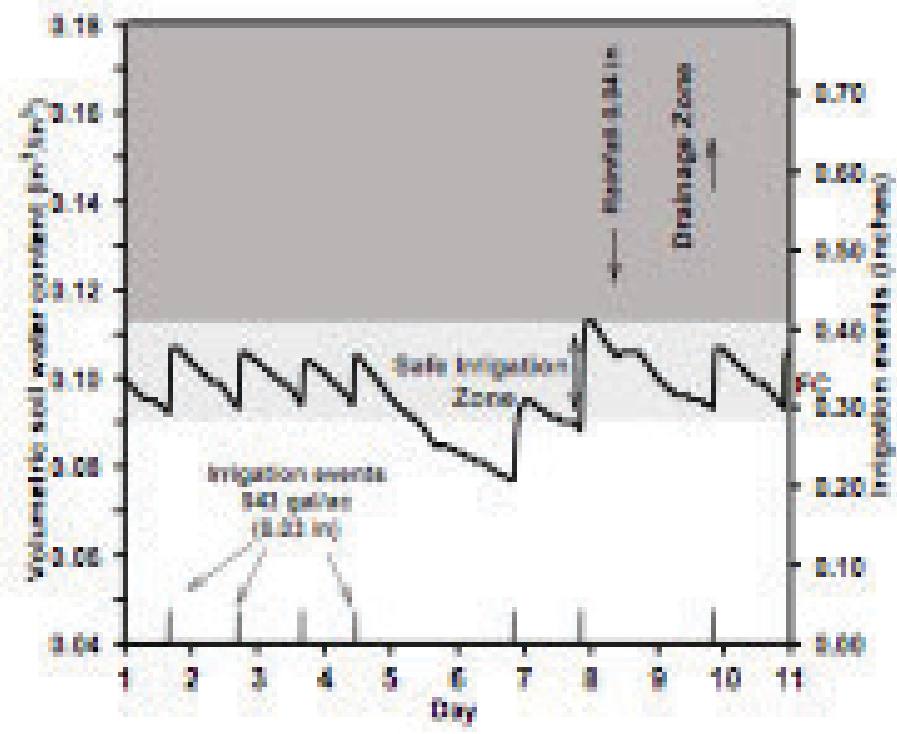

Figure 3. Example of adequate irrigation management using soil moisture sensors for monitoring the volumetric soil moisture content in the upper soil layer (0-to-6-inch depth) on drip irrigation under plastic-mulched conditions for sandy soils. The black line indicates volumetric soil water content using soil moisture sensors. The gray line indicates irrigation events, each single daily irrigation event having a volume application of $943 \mathrm{gal} / \mathrm{A}$ (0.03 in). The dotted line indicates the soil field capacity line. Arrows indicate rainfall events.
Conversely, Figure 3 shows "adequate" irrigation applications for a 10-day period. In this case, the irrigation event started exclusively when the volumetric soil water content reached a set threshold. For this particular situation, the soil field capacity was known, so the irrigation events started when the volumetric soil moisture content reached values below field capacity (or $0.09 \mathrm{in}^{3} / \mathrm{in}^{3}$ ). However, to maintain the soil volumetric water content in the "safe irrigation zone," a previous determination of the length of the irrigation is necessary to avoid overirrigation. Additional information about irrigation depths can be obtained in Microirrigation in Mulched Bed Production Systems: Irrigation Depths at https://edis.ifas.ufl.edu/ae049.

The example in Figure 3 received irrigation of $943 \mathrm{gal} / \mathrm{A}$ (equivalent to 0.03 in for overhead or seepage irrigation, or $6 \mathrm{gal} / 100 \mathrm{ft}$ for drip irrigation with 6 -foot bed centers in plasticulture). This irrigation depth was sufficient to increase the volumetric water content to a given moisture without exceeding the "safe irrigation zone." On average, the volumetric soil water content was maintained close to the field capacity, keeping water and nutrients in the root zone. For this particular example, there was no deep water percolation. In addition, with the information of the soil water status, the irrigation manager might decide to not irrigate if the soil moisture content is at a satisfactory level. For example, on day 8, due to a rainfall event of 0.04 in, there was no need for irrigation, because the soil moisture was above the field capacity, and therefore the irrigation event of day 8 was skipped. On the other hand, this "precise" irrigation management requires very close attention by the irrigation manager. For a given reason (such as pump issue), the irrigation was ceased on day 5 and it was resumed late in day 6 . As a result, soil water storage decreased below the safe irrigation zone, and if the water shortage was prolonged, the plants could become water-stressed.

\section{Installation and Placing of Soil Moisture Sensor Devices}

The use of soil moisture monitoring devices (volumetric or soil water tension) has potential to save irrigation water in a given vegetable area by reducing the number of unnecessary irrigation events. However, the effectiveness of these sensors depends on proper installation in representative locations within vegetable fields. These sensors may be used to monitor water table levels in seepage irrigation.

Sensors should be installed in the root zone of the plants to be irrigated. Most of the vegetable crops have $80 \%$ to $90 \%$ of the root zone in the upper 12 in, which generally is the soil layer with higher water depletion by evapotranspiration. 
For vegetable crops cultivated in rows and irrigated by drip tapes, the sensors should be installed 2-3 in away from the plant row. For single-row crops (such as tomato, eggplant, or watermelon), the sensor should be placed on the opposite side from the drip tape; for double-row crops (pepper, squash), the sensors should be placed in between the drip tape and plant rows.

Sensors need to be in good contact with the soil after installation; there should be no air gaps surrounding the sensor. Soil should be packed firmly but not excessively around the sensor. Alternatively, sensors can be installed in a slurry of wetted soil that was removed for the sensor install. Using a slurry, the consistency of cake batter, can also provide the user with an initial calibration of the sensor for the determination of field capacity seen in Figure 1. In plasticulture, after the installation, the area above the sensor should be re-covered with plastic and sealed with tape.

\section{Soil Moisture Sensor Data Interpretation}

Soil moisture sensors can provide information on the depth of an irrigation or rainfall event, at what depth and in what quantity crop roots are extracting water from the soil, when irrigation is necessary, and more. However, this information is not always intuitive without some guidance. For a closer look at various soil moisture sensors and their data interpretation, visit the UF/IFAS North Florida Research and Education Center-Suwannee Valley YouTube channel and view the soil moisture sensor playlist (https:// www.youtube.com/playlist?list=PLn-umAc9HXgDyMWNdstplSR9QWUiU9H8). For more information on BMPs for irrigation, visit https://www.youtube.com/channel/UCKECrzl3EelKV1DAyIT1NLw (UF/IFAS-NFREC Suwannee Valley).

\section{Crop Water Requirement (ET)}

Crop water requirements depend on crop type, stage of growth, and evaporative demand. Evaporative demand is termed evapotranspiration (ET) and may be estimated using historical or current weather data. Generally, reference evapotranspiration (ETo) is determined for use as a base level. By definition, ETo represents the water use from a uniform green cover surface that is actively growing and well-watered (such as turf or a grass-covered area).

Historical daily averages of Penman-method ETo values, expressed in units of acre-inches and gallons per acre, are available for six Florida regions (Table 4). While these values are provided as guidelines for management purposes, actual values may vary above and below these values, requiring individual site adjustments. Actual daily values may be as much as $25 \%$ higher on days that are hotter and drier than normal or as much as $25 \%$ lower on days that are cooler or more overcast than normal. Real time ETo estimates can be found at the Florida Automated Weather Network (FAWN) internet site (https://fawn.ifas.ufl.edu). For precise management, SWT or soil moisture should be monitored daily in the field.

Crop water use (ETc) is related to ETo by a crop coefficient (Kc), which is the ratio of ETc to the reference value ETo (Eq. [2]). Because different methods exist for estimating ETo, it is very important to use Kc coefficients that were derived using the same ETo estimation method as will be used to determine the crop water requirements. Also, Kc values for the appropriate stage of growth (Table 5 and 6 ; Figure 3 ) and production system (Tables 7 and 8) must be used.

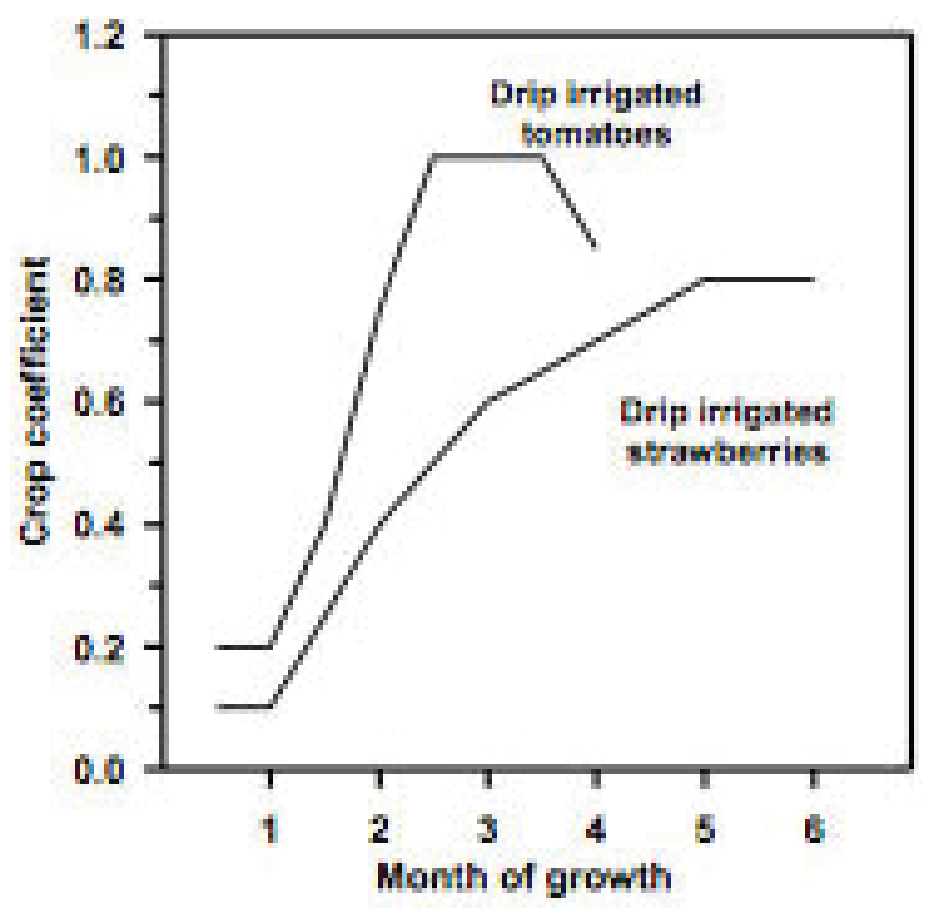

Figure 4. Crop coefficient of drip-irrigated tomato and strawberry.

With drip irrigation where the wetted area is limited and plastic mulch is often used, Kc values are lower to reflect changes in row spacing and mulch use. Plastic mulches substantially reduce evaporation of water from the soil surface. Associated with the reduction of evaporation is a general increase in transpiration. Even though the transpiration rates under mulch may increase by an average of $10 \%-30 \%$ over the season as compared to no-mulch systems, overall water-use values decrease by an average of $10 \%-30 \%$ due to the reduction in soil evaporation. ETo may be estimated from atmometers (also called modified Bellani plates) by using an adjustment factor. During days without rainfall, ETo may be estimated from evaporation 
from an ET gauge $(\mathrm{Ea})$ as $\mathrm{ETo}=\mathrm{Ea} / 0.89$. On rainy days $(>0.2$ in) $\mathrm{ETo}=\mathrm{Ea} / 0.84$.

\section{Eq. [2] Crop water requirement $=$ Crop coefficient $\times$} Reference evapotranspiration

$\mathrm{ETc}=\mathrm{Kc} \times \mathrm{ETo}$

\section{Soil Water-Holding Capacity and the Need to Split Irrigations}

Appropriate irrigation scheduling and matching irrigation amounts with the water-holding capacity of the effective root zone may help minimize the incidence of excess leaching associated with overirrigation. In Florida sandy soils, the amount of water that can be stored in the root zone and be available to the plants is limited. Usually, it is assumed that approximately 0.75 in of water can be stored in every foot of the root zone. Only half of that should be used before the next irrigation to avoid plant stress and yield reduction (this will help maintain SWT below $15 \mathrm{cb}$ ). Any additional water will be lost by deep percolation below the root zone.

Table 8 gives the approximate amount of water that can be applied at each event in Florida sandy soil under different production systems. When the calculated volume of water to be applied in one day exceeds the values in Table 7, then it is necessary to split applications. The number of split irrigations can be determined by dividing the irrigation requirement (Eq. [1]) by the numbers in Table 8 , and rounding up the result to the nearest whole number. Splitting irrigation reduces risks of water loss through deep percolation and nutrient leaching. Sandy soil with the available water-holding capacity of $0.75 \mathrm{in} / \mathrm{ft}$ was assumed in these calculations. If a soil contains more clay or organic matter, the amount of water applied during one irrigation event and stored in the root zone can be increased. To ensure that the water is not lost from the roots, it is recommended to check the depth of wetting after irrigation by digging out a perpendicular profile to the drip line and observing the wetted pattern.

\section{Example}

As an example, consider drip-irrigated tomatoes on 6-foot center beds, grown under a plastic mulch production system in the central west area (sandy soils). For plants in growth Stage 5 the crop coefficient is 0.85 (Table 7). If this period of growth occurred in May, the corresponding ETo value is $4,887 \mathrm{gal} / \mathrm{A} /$ day (Table 4 ). Daily crop water use would be estimated as:
ETcrop $=(0.85) \times(4,887 \mathrm{gal} / \mathrm{A} /$ day $)=4,153 \mathrm{gal} / \mathrm{A} / \mathrm{day}$

If the drip irrigation system can apply water to the root zone of the crop with an application efficiency of $80 \%$, the irrigation requirement would be

\section{Irrigation Requirement $=(4,153 \mathrm{gal} / \mathrm{A} / \mathrm{day}) /(0.80)=$ $5,192 \mathrm{gal} / \mathrm{A} / \mathrm{day}$}

If the maximum water application in one irrigation event for this type of soil is $1,700 \mathrm{gal} / \mathrm{A} /$ irrigation, then the irrigation will have to be split:

Number of events $=(5,292 \mathrm{gal} / \mathrm{A} / \mathrm{day}) /(1,700 \mathrm{gal} / \mathrm{A} / \mathrm{day} /$ irrigation event) $=3.1$, rounded up to 4 irrigation events each of $5,292 / 4=1,323 \mathrm{gal} / \mathrm{A}$

Therefore, in this example, four irrigations of $1,323 \mathrm{gal} / \mathrm{A}$ each will be needed to replace ETc, not exceed the soil water-holding capacity. This amount of water would be a good estimate for scheduling purposes under average growth and average May climatic conditions. However, field moisture plant status should be also monitored to determine if irrigation levels need to be increased or reduced. While deficit irrigation will reduce fruit size and plant growth, excessive irrigation may leach nutrients from the active root system. This may also reduce plant growth and yield. 
Table 1. Application efficiency for water delivery systems used in Florida.

\begin{tabular}{|l|c|}
\hline \multicolumn{1}{|c|}{ Irrigation System } & Application Efficiency (Ea) \\
\hline Overhead & $60 \%-80 \%$ \\
\hline Seepage & $20 \%-70 \%$ \\
\hline Drip $^{2}$ & $80 \%-95 \%$ \\
\hline $\begin{array}{l}{ }^{1} \text { Ea greater than 50\% are not expected unless tailwater recovery is used. } \\
{ }^{2} \text { With or without plastic mulch }\end{array}$ \\
\hline
\end{tabular}

Table 2. Levels of water management and corresponding irrigation scheduling method.

\begin{tabular}{|c|l|}
\hline $\begin{array}{c}\text { Water Mgt. } \\
\text { Level }\end{array}$ & \multicolumn{1}{c|}{ Irrigation Scheduling Method } \\
\hline 0 & Guessing (irrigate whenever); not recommended \\
\hline 1 & Using the "feel-and-see" method; see nrcs.usda.gov/wps/portal/nrcs/detail/wy/soils/?cid=nrcs142p2_026833 \\
\hline 2 & Using systematic irrigation (Example: 0.75 in every 4th day; or 2 hr every day) \\
\hline 3 & Using a soil water tension measuring tool or soil moisture sensor to start irrigation \\
\hline 4 & Scheduling irrigation and apply amounts based on a budgeting procedure and checking actual soil water status \\
\hline 5 a & $\begin{array}{l}\text { Adjusting irrigation to plant water use (ETo), and using a dynamic water balance based on a budgeting procedure and plant } \\
\text { stage of growth, together with using a soil water tension measuring tool or soil moisture sensor }\end{array}$ \\
\hline aRecommended method
\end{tabular}

Table 3. Summary of irrigation scheduling guidelines for vegetable crops grown in Florida.

\begin{tabular}{|c|c|c|}
\hline \multirow[b]{2}{*}{ Irrigation Scheduling Component } & \multicolumn{2}{|c|}{ Irrigation System ${ }^{1}$} \\
\hline & Seepage $^{2}$ & Drip $^{3}$ \\
\hline 1-Target water application rate & $\begin{array}{l}\text { Keep water table between 18- and 24-inch } \\
\text { depth. }\end{array}$ & $\begin{array}{l}\text { Historical weather data or crop evapotranspiration } \\
\text { (ETc) calculated from reference ET or Class A pan } \\
\text { evaporation. }\end{array}$ \\
\hline $\begin{array}{l}\text { 2-Fine-tune application with soil } \\
\text { moisture measurement }\end{array}$ & $\begin{array}{l}\text { Monitor water table depth with observation } \\
\text { wells. }\end{array}$ & $\begin{array}{l}\text { Maintain soil moisture level in the root zone } \\
\text { between } 8 \text { and } 15 \text { cbar (or } 8 \% \text { and } 12 \% \text { available } \\
\text { soil moisture. }\end{array}$ \\
\hline $\begin{array}{l}3 \text {-Determine the contribution of } \\
\text { rainfall }\end{array}$ & $\begin{array}{l}\text { Typically, } 1 \text {-inch rainfall raises the water table } \\
\text { by } 1 \text { foot. }\end{array}$ & $\begin{array}{l}\text { Poor lateral water movement on sandy and rocky } \\
\text { soils limits the contribution of rainfall to crop water } \\
\text { needs to (1) foliar absorption and cooling of foliage } \\
\text { and ( } 2 \text { ) water funneled by the canopy through the } \\
\text { plan hole. }\end{array}$ \\
\hline 4-Rule for splitting irrigation & $\begin{array}{l}\text { Not applicable. However, a water budget can be } \\
\text { developed. }\end{array}$ & $\begin{array}{l}\text { Irrigations greater than } 12 \text { and } 50 \text { gal/100ft (or } 30 \\
\text { min and } 2 \text { hrs for drip tapes with medium flow-rate) } \\
\text { when plants are small and fully grown, respectively } \\
\text { are likely to push the water front being below the } \\
\text { root zone. }\end{array}$ \\
\hline 5-Recordkeeping & $\begin{array}{l}\text { Irrigation amount applied and total rainfall } \\
\text { received }{ }^{4} \\
\text { Days of system operation. }\end{array}$ & $\begin{array}{l}\text { Irrigation amount applied and total rainfall } \\
\text { received }{ }^{4} \\
\text { Daily irrigation schedule. }\end{array}$ \\
\hline \multicolumn{3}{|c|}{$\begin{array}{l}{ }^{1} \text { Efficient irrigation scheduling also requires a properly designed and maintained irrigation system } \\
{ }^{2} \text { Practical only when a spodic layer is present in the field } \\
{ }^{3} \text { On deep sandy soils } \\
{ }^{4} \text { Required by the BMPs }\end{array}$} \\
\hline
\end{tabular}


Table 4. Historical Penman method reference evapotranspiration (ETo) for six Florida regions expressed in (A) inches per day and (B) gallons per acre per day'.

\begin{tabular}{|c|c|c|c|c|c|c|}
\hline Month & Northwest & Northeast & Central & Central West & Southwest & Southeast \\
\hline \multicolumn{7}{|c|}{ Inches per day (A) } \\
\hline Jan & 0.06 & 0.07 & 0.07 & 0.07 & 0.08 & 0.08 \\
\hline Feb & 0.07 & 0.08 & 0.10 & 0.10 & 0.11 & 0.11 \\
\hline Mar & 0.10 & 0.10 & 0.12 & 0.13 & 0.13 & 0.13 \\
\hline Apr & 0.13 & 0.14 & 0.16 & 0.16 & 0.17 & 0.17 \\
\hline May & 0.16 & 0.16 & 0.18 & 0.18 & 0.18 & 0.18 \\
\hline Jun & 0.17 & 0.16 & 0.18 & 0.18 & 0.18 & 0.17 \\
\hline Jul & 0.17 & 0.16 & 0.17 & 0.17 & 0.18 & 0.18 \\
\hline Aug & 0.15 & 0.15 & 0.17 & 0.16 & 0.17 & 0.16 \\
\hline Sep & 0.13 & 0.13 & 0.14 & 0.14 & 0.15 & 0.14 \\
\hline Oct & 0.09 & 0.10 & 0.11 & 0.11 & 0.12 & 0.12 \\
\hline Nov & 0.07 & 0.07 & 0.08 & 0.08 & 0.09 & 0.09 \\
\hline Dec & 0.05 & 0.06 & 0.06 & 0.07 & 0.07 & 0.07 \\
\hline \multicolumn{7}{|c|}{ Gallons per acre per day² (B) } \\
\hline Jan & 1629 & 1901 & 1901 & 1901 & 2172 & 2172 \\
\hline Feb & 1901 & 2172 & 2715 & 2715 & 2987 & 2987 \\
\hline Mar & 2715 & 2715 & 3258 & 3530 & 3530 & 3530 \\
\hline Apr & 3530 & 3801 & 4344 & 4344 & 4616 & 4616 \\
\hline May & 4344 & 4344 & 4887 & 4887 & 4887 & 4887 \\
\hline Jun & 4616 & 4344 & 4887 & 4887 & 4887 & 4616 \\
\hline Jul & 4616 & 4344 & 4616 & 4616 & 4887 & 4887 \\
\hline Aug & 4073 & 4073 & 4616 & 4344 & 4616 & 4344 \\
\hline Sept & 3530 & 3530 & 3801 & 3801 & 4073 & 3801 \\
\hline Oct & 2444 & 2715 & 2987 & 2987 & 3258 & 3258 \\
\hline Nov & 1901 & 1901 & 2172 & 2172 & 2444 & 2444 \\
\hline Dec & 1358 & 1629 & 1629 & 1629 & 1901 & 1901 \\
\hline
\end{tabular}

${ }^{1}$ Assuming water application over the entire area, i.e., sprinkler or seepage irrigation with $100 \%$ efficiency. See Table 1 for conversion for taking into account irrigation system efficiency.

${ }^{2}$ Calculation: for overhead or seepage irrigation, $(B)=(A) \times 27,150$. To convert values for drip irrigation $(C)$ use $(C)=(B) \times$ bed spacing/435.6.

For example, for 6 -foot bed spacing and single drip line, $C$ in southwest Florida in January is $C=2,172 \times 6 / 435.6=30 \mathrm{gal} / 100 \mathrm{ft} / \mathrm{day}$. 
Table 5. Description of growth stages (plant appearance and estimated number of weeks) for most vegetable crops grown in the spring in Florida'.

\begin{tabular}{|c|c|c|c|c|c|c|}
\hline Crop & Stage 1 & Stage 2 & Stage 3 & Stage 4 & Stage 5 & $\begin{array}{c}\text { Expected } \\
\text { Growing Season } \\
\text { (Weeks) }\end{array}$ \\
\hline Bean & Small plants $2-3$ & $\begin{array}{l}\text { Growing plants } \\
\text { 3-4 }\end{array}$ & $\begin{array}{l}\text { Pod enlargement } \\
\qquad 2-3\end{array}$ & $\begin{array}{c}\text { Pod maturation } \\
\qquad 2-3\end{array}$ & & $9-10$ \\
\hline $\begin{array}{l}\text { Cabbage, cauliflower, } \\
\text { chinese cabbage }\end{array}$ & Small plants 2-3 & $\begin{array}{l}\text { Growing plants } \\
5-6\end{array}$ & $\begin{array}{c}\text { Head } \\
\text { development 3-4 }\end{array}$ & & & $10-12$ \\
\hline $\begin{array}{l}\text { Cantaloupe } \\
\text { (muskmelon) }\end{array}$ & 6-in vine $1-2$ & 12 -in vine $3-4$ & First flower 3-4 & $\begin{array}{c}\text { Main fruit } \\
\text { production 2-3 }\end{array}$ & $\begin{array}{l}\text { Late fruit } \\
\text { production 2-3 }\end{array}$ & $11-12$ \\
\hline Carrot & Small plants 1-2 & $\begin{array}{l}\text { Growing plants } \\
\qquad 3-4\end{array}$ & $\begin{array}{c}\text { Root } \\
\text { development 5-7 }\end{array}$ & Final growth 1-2 & & $10-13$ \\
\hline Cucumber & 6-in vine $1-2$ & 12-in vine $2-3$ & $\begin{array}{l}\text { Fruit production } \\
\qquad 6-7\end{array}$ & Late season 1-2 & & $10-12$ \\
\hline Eggplant & Small plants $2-3$ & $\begin{array}{l}\text { Growing plants } \\
\qquad 2-3\end{array}$ & $\begin{array}{l}\text { Fruit production } \\
\qquad 6-7\end{array}$ & Late season $2-3$ & & $12-13$ \\
\hline Potato & $\begin{array}{l}\text { Small plants } \\
\text { (after hilling) 2-4 }\end{array}$ & $\begin{array}{l}\text { Large plants } \\
\text { (vegetative } \\
\text { growth) 4-6 }\end{array}$ & $\begin{array}{l}\text { First flower (tube } \\
\text { initiation and } \\
\text { bulking) 3-5 }\end{array}$ & $\begin{array}{l}\text { Maturation (top } \\
\text { dies) } 2-4\end{array}$ & & $12-14$ \\
\hline Okra & Small plants $2-3$ & $\begin{array}{c}\text { Growing plants } \\
2-3\end{array}$ & $\begin{array}{l}\text { Pod production } \\
7-8\end{array}$ & Late season 1-2 & & $12-13$ \\
\hline Onion & Small plants 2-4 & $\begin{array}{l}\text { Growing plants } \\
4-5\end{array}$ & $\begin{array}{c}\text { Bulb } \\
\text { development 6-8 }\end{array}$ & $\begin{array}{l}\text { Maturation (top } \\
\text { falls) 1-2 }\end{array}$ & & $13-16$ \\
\hline Pepper & Small plants $2-3$ & $\begin{array}{c}\text { Growing plants } \\
2-3\end{array}$ & $\begin{array}{c}\text { Pod production } \\
7-8\end{array}$ & Last bloom 1-2 & Last harvest 1 & $13-15$ \\
\hline Pumpkin (bush) & Small plants $2-3$ & First flower 2-3 & $\begin{array}{l}\text { Fruit enlargement } \\
\qquad 5-6\end{array}$ & Harvest 1-2 & & $9-11$ \\
\hline Pumpkin (vining) & 6 -in vines $2-3$ & 12 -in vines $2-3$ & Small fruit 3-4 & Large fruit 2-3 & Harvest 1-2 & $13-15$ \\
\hline Radish & Small plants $1-2$ & Rapid growth 2-4 & & & & $3-5$ \\
\hline Strawberry & $\begin{array}{l}\text { Young plants } \\
\text { October }\end{array}$ & $\begin{array}{l}\text { Growing plants } \\
\text { November }\end{array}$ & $\begin{array}{l}\text { Early harvest } \\
\text { December- } \\
\text { January }\end{array}$ & $\begin{array}{c}\text { Main harvest } \\
\text { period February- } \\
\text { March }\end{array}$ & Late harvest April & $23-30$ \\
\hline $\begin{array}{l}\text { Summer squash } \\
\text { (crookneck, } \\
\text { straightneck, } \\
\text { zucchini) }\end{array}$ & Small plants 1-2 & $\begin{array}{l}\text { Growing plants } \\
\qquad 2-3\end{array}$ & $\begin{array}{l}\text { Fruit production } \\
\qquad 3-4\end{array}$ & $\begin{array}{l}\text { Late fruit } \\
\text { production } 1\end{array}$ & & $7-9$ \\
\hline Sweet corn & Small plants 3-4 & Large plants 5-8 & $\begin{array}{l}\text { Ear development } \\
\qquad 2-3\end{array}$ & & & $10-15$ \\
\hline Sweetpotato & $\begin{array}{l}\text { Early vine growth } \\
\qquad 2-3\end{array}$ & $\begin{array}{l}\text { Expanding vines } \\
\qquad 5-6\end{array}$ & $\begin{array}{l}\text { Storage root } \\
\text { enlargement } \\
6-10\end{array}$ & & Late season & $13-17$ \\
\hline Tomato & Small plants $2-3$ & 1st bloom 2-3 & $\begin{array}{c}\text { 2nd, 3rd bloom } \\
6-7\end{array}$ & Harvest 1-2 & Late harvest 1-2 & $12-14$ \\
\hline Watermelon & 6 -in vines $2-3$ & 12 -in vines $2-3$ & Small fruit 3-4 & Large fruit 2-3 & Harvest 1-2 & $13-15$ \\
\hline
\end{tabular}


Table 6. Crop coefficient estimates for use with the ETo values in Table 4 and growth stages in Table 5 for unmulched crops. (Actual values will vary with time of planting, soil conditions, cultural conditions, length of growing season and other site-specific factors).

\begin{tabular}{|c|c|c|}
\hline Crop & Growth Stage & Crop Coefficient ${ }^{1}$ \\
\hline All field-grown vegetables & $\begin{array}{l}1 \\
2\end{array}$ & $\begin{array}{c}0.20^{2} \text { to } 0.40^{3} \\
\text { Stage } 1^{4} \text { value to Stage } 3 \text { value (see } \\
\text { Figure } 4 \text { ) }\end{array}$ \\
\hline Legumes: sandbean, lima bean, and southernpea & $\begin{array}{l}3 \\
4\end{array}$ & $\begin{array}{l}0.95^{5} \\
0.85^{5}\end{array}$ \\
\hline Beet & $\begin{array}{l}3 \\
4\end{array}$ & $\begin{array}{l}1.00 \\
0.90\end{array}$ \\
\hline $\begin{array}{l}\text { Cole crops: Broccoli, brussels sprouts, cabbage, cauliflower, collards, kale, } \\
\text { mustard, turnip }\end{array}$ & $\begin{array}{l}3 \\
4 \\
3 \\
4\end{array}$ & $\begin{array}{l}0.95 \\
0.80^{5} \\
0.90^{5} \\
1.00^{5}\end{array}$ \\
\hline Carrot & $\begin{array}{l}3 \\
4\end{array}$ & $\begin{array}{l}1.00 \\
0.70\end{array}$ \\
\hline Celery & $\begin{array}{l}3 \\
4\end{array}$ & $\begin{array}{l}1.00 \\
0.90\end{array}$ \\
\hline Cucurbits: cucumber, cantaloupe, pumpkin, squash, watermelon & $\begin{array}{l}3 \\
4\end{array}$ & $\begin{array}{l}0.90 \\
0.70\end{array}$ \\
\hline Lettuce, endive, escarole & $\begin{array}{l}3 \\
4\end{array}$ & $\begin{array}{l}0.95 \\
0.90\end{array}$ \\
\hline Okra & $\begin{array}{l}3 \\
4\end{array}$ & $\begin{array}{l}1.00^{5} \\
0.90^{5}\end{array}$ \\
\hline Onion (dry) & $\begin{array}{l}3 \\
4\end{array}$ & $\begin{array}{l}0.95 \\
0.75\end{array}$ \\
\hline Onion (green) & 3 and 4 & 0.95 \\
\hline Parsley & 3 & $1.00^{5}$ \\
\hline Potato & $\begin{array}{l}3 \\
4\end{array}$ & $\begin{array}{l}1.10 \\
0.70\end{array}$ \\
\hline Radish & $\begin{array}{l}3 \\
4\end{array}$ & $\begin{array}{l}0.80 \\
0.75\end{array}$ \\
\hline Spinach & $\begin{array}{l}3 \\
4\end{array}$ & $\begin{array}{l}0.95 \\
0.90\end{array}$ \\
\hline Sweet corn & $\begin{array}{l}3 \\
4\end{array}$ & $\begin{array}{l}1.10 \\
1.00\end{array}$ \\
\hline Sweetpotato & $\begin{array}{l}3 \\
4\end{array}$ & $\begin{array}{l}1.10^{5} \\
0.70^{5}\end{array}$ \\
\hline \multicolumn{3}{|c|}{$\begin{array}{l}\text { 'adapted from Doorenbos, J., and W. O. Pruitt. 1977. "Crop Water Requirements." Irrigation and Drainage Paper No. 24, (rev.) Food and } \\
\text { Agriculture Organization (FAO), Rome; and Allen, R. G., L. S. Pereira, D. Raes, and M. Smith. 1998. “Crop Evapotranspiration: Guidelines for } \\
\text { Computing Crop Water Requirements." FAO, Rome. } \\
{ }^{2} \text { low plant population; wide row spacing } \\
{ }^{3} \text { high plant population; close row spacing } \\
{ }^{4} 0.30 \text { or Kc value from Stage } 1 \\
{ }^{5} \text { values estimated from similar crops }\end{array}$} \\
\hline
\end{tabular}


Table 7. Crop coefficient estimates (Kc) for use with ETo values in Table 4 and growth stages in Table 5 for selected crops grown in a plasticulture system. ${ }^{1}$

\begin{tabular}{|c|c|c|}
\hline Crop & Growth Stage & Crop Coefficient (Kc) \\
\hline Cantaloupe $^{1}$ & $\begin{array}{l}1 \\
2 \\
3 \\
4 \\
5\end{array}$ & $\begin{array}{c}0.35 \\
0.6 \\
0.85 \\
0.85 \\
0.85\end{array}$ \\
\hline Cucumber $^{1}$ & $\begin{array}{l}1 \\
2 \\
3 \\
4\end{array}$ & $\begin{array}{c}0.25 \\
0.5 \\
0.9 \\
0.75\end{array}$ \\
\hline Summer squash ${ }^{1}$ & $\begin{array}{l}1 \\
2 \\
3 \\
4\end{array}$ & $\begin{array}{c}0.3 \\
0.55 \\
0.9 \\
0.8\end{array}$ \\
\hline Strawberry (4-foot bed centers) ${ }^{2}$ & $\begin{array}{l}1 \\
2 \\
3 \\
4 \\
5\end{array}$ & $\begin{array}{l}0.4 \\
0.5 \\
0.6 \\
0.8 \\
0.8\end{array}$ \\
\hline Tomato (6-foot bed centers) ${ }^{3}$ & $\begin{array}{l}1 \\
2 \\
3 \\
4 \\
5\end{array}$ & $\begin{array}{c}0.4 \\
0.75 \\
1.0 \\
1.0 \\
0.85\end{array}$ \\
\hline Watermelon (8-foot bed center) ${ }^{1}$ & $\begin{array}{l}1 \\
2 \\
3 \\
4 \\
5\end{array}$ & $\begin{array}{l}0.3 \\
0.5 \\
0.7 \\
0.9 \\
0.8\end{array}$ \\
\hline \multicolumn{3}{|c|}{$\begin{array}{l}{ }^{1} \text { Adapted from Tables } 12 \text { and } 25 \text { in Allen, R.G., L. S. Pereira, D. Raes, and M. Smith. 1998. "Crop Evapotranspiration: Guidelines for Computing } \\
\text { Crop Water Requirements." Food and Agriculture Organization of the United Nations, Rome. } \\
{ }^{2} \text { Adapted from Clark et al. 1993. "Water Requirements and Crop Coefficients for Tomato Production in Southwest Florida." Southwest Florida } \\
\text { Water Management District, Brandon, FL. } \\
{ }^{3} \text { Adapted from Clark et al. 1996. "Water Requirements and Crop Coefficients of Drip-Irrigated Strawberry Plants." Transactions of the ASAE 39: } \\
905-913 .\end{array}$} \\
\hline
\end{tabular}

Table 8. Maximum water application (in gallons per acre and in gallons/100 ft) in one irrigation event for various production systems on sandy soil (available water-holding capacity $0.75 \mathrm{in} / \mathrm{ft}$ and $50 \%$ soil water depletion). Split irrigations may be required during peak water requirement.

\begin{tabular}{|c|c|c|c|c|c|c|c|c|c|}
\hline $\begin{array}{l}\text { Wetting } \\
\text { Width } \\
\text { (ft) }\end{array}$ & $\begin{array}{c}\text { Gal/100 } \\
\mathrm{ft} \text { to Wet } \\
\text { Depth of } \\
1 \mathrm{ft}\end{array}$ & $\begin{array}{c}\text { Gal/100 } \\
\mathrm{ft} \text { to Wet } \\
\text { Depth of } \\
1.5 \mathrm{ft}\end{array}$ & $\begin{array}{c}\text { Gal/100 } \\
\mathrm{ft} \text { to Wet } \\
\text { Depth of } \\
2 \mathrm{ft}\end{array}$ & $\begin{array}{c}\text { Bed } \\
\text { Spacing } \\
\text { (ft) }\end{array}$ & Vegetable Crop & $\begin{array}{c}\text { Bed } \\
\text { Length } \\
(100 \mathrm{lb} / \\
\text { Acre })\end{array}$ & $\begin{array}{c}\text { Gal/Acre } \\
\text { to Wet } \\
\text { Depth } \\
\text { of } 1 \mathrm{ft}\end{array}$ & $\begin{array}{c}\text { Gal/Acre } \\
\text { to Wet } \\
\text { Depth of } \\
1.5 \mathrm{ft}\end{array}$ & $\begin{array}{c}\text { Gal/Acre } \\
\text { to Wet } \\
\text { Depth of } \\
2 \mathrm{ft}\end{array}$ \\
\hline 1.0 & 24 & 36 & 48 & $\begin{array}{l}4 \\
5 \\
6 \\
8\end{array}$ & $\begin{array}{l}\text { - Lettuce, strawberry } \\
\text { - Muskmelon } \\
\text { - Broccoli, cabbage, cauliflower, } \\
\text { eggplant, okra, pepper, } \\
\text { pumpkin (bush), summer } \\
\text { squash, tomato } \\
\text { - Pumpkin (vining), watermelon }\end{array}$ & $\begin{array}{c}109 \\
87 \\
73 \\
55\end{array}$ & $\begin{array}{l}2,600 \\
2,100 \\
1,700 \\
1,300\end{array}$ & $\begin{array}{l}3,800 \\
3,100 \\
2,600 \\
1,900\end{array}$ & $\begin{array}{l}5,100 \\
4,100 \\
3,500 \\
2,600\end{array}$ \\
\hline 1.5 & 36 & 54 & 72 & $\begin{array}{l}4 \\
5 \\
6 \\
8\end{array}$ & $\begin{array}{l}\text { - Lettuce, strawberry } \\
\text { - Muskmelon } \\
\text { - Broccoli, cabbage, cauliflower, } \\
\text { eggplant, okra, pepper, } \\
\text { pumpkin (bush), summer } \\
\text { squash, tomato } \\
\text { - Pumpkin (vining), watermelon }\end{array}$ & $\begin{array}{c}109 \\
87 \\
73 \\
55\end{array}$ & $\begin{array}{l}3,800 \\
3,100 \\
2,600 \\
1,900\end{array}$ & $\begin{array}{l}5,800 \\
4,700 \\
3,900 \\
3,000\end{array}$ & $\begin{array}{l}7,600 \\
6,200 \\
5,200 \\
3,900\end{array}$ \\
\hline
\end{tabular}

